\title{
Catalysts for Rapid Internationalization of SMEs: Born Globals in South Korea
}

\author{
Anura Amarasena \\ Sol International School, Woosong University, South Korea \\ Received October 20, 2019; Revised November 18, 2019; Accepted December 4, 2019
}

Copyright $\subseteq 2020$ by authors, all rights reserved. Authors agree that this article remains permanently open access under the terms of the Creative Commons Attribution License 4.0 International License

\begin{abstract}
This research article analyses the present explanations of the phenomenon of born globals, in particular within the context of South Korea with the objective of identifying the characteristics that can affect the rapid internationalization of small and medium-sized enterprises (SMEs). The traditional theories of internationalization have been built with the aim of illuminating the internationalization of large multinational enterprises (MNEs). These models explain that doing international business develops progressively over time and firms establish themselves domestically before gradually turning into global markets. However, those traditional theories were unable to clarify the way of acting of companies which include SMEs that leapfrog or rising development of born globals. This has created a requirement for a new interpretation of internationalization. As an export-led country, born globals play an important role in improving South Korea's competitiveness. This review has significant implications which propose that many characteristics can affect the rapid internationalization of SMEs in South Korea even though they are still not precisely clear. Thus the paper highlights that wider empirical research is significant to this country for understanding the specific characteristics that are responsible for the rapid internationalization of their SMEs.
\end{abstract}

Keywords Exporting, Born Globals, Global Start-ups, International New Ventures, High Technology Start-ups, International Business (IB), Small and Medium-sized Enterprises [SMEs], South Korea

\section{Introduction}

The contribution of SMEs to national economies of many countries around the world is uncontested as the SMEs sector contributes in a number of ways for the long-run development in their economies [2, 5-12, 25, 39, 71]. Research evidence shows that SMEs enter into international business within a shorter period than before and they are effectively carrying out their international businesses quickly. These globally active companies have a propensity to grow much quicker than the small firms that serve solely domestic markets [2]. As a result, their global business activities are drawing great interest from researchers around the world. In spite of the vital role of SMEs in the economic growth of many counties, literature shows that most research attention has been concentrated on further promotion of the big conglomerates in South Korea [66]. However, over a few years, the Korean government has started paying attention to SMEs reassuring their access to finance, markets, and technology, independent of a chaebol and large companies [59]. This indicates the government recognition of the significant contribution of South Korean SMEs' to the overall performance of the South Korean economy [74].

In the current state of a relatively globalized economy, many companies including SMEs are interested to expand their business to worldwide markets. The literature on born globals has revealed the potential of SMEs' early internationalization that leapfrog or rising development of born globals which cannot be explained by the traditional theories of internationalization. It is observed that these firms either have fully ignored their home market while coming into the global markets or selected to enter the domestic market and global markets promptly [49, 55]. This abrupt rise has led to a replacement breed of exporters identified in various parts of the globe as born globals, global start-ups, international new ventures, and high technology start-ups. The research outcomes on born globals have shown the power of small and medium-sized enterprises' (SMEs) fast internationalization [4, 10, 17].

The traditional theories of internationalization have built with the aim of illuminating the internationalization of large multinational enterprises (MNEs). These models only explain that doing international business develops 
progressively over time and firms establish themselves domestically before gradually turning into global markets. This has created a requirement for a new interpretation of internationalization. Review of literature from multiple countries on the born global conception has indicated that there are varied explanations for the dynamics that drive their internationalization of SMEs. As an export-led country, born globals play an important role in improving South Korea's competitiveness. However, available literature indicates that the research analysis was undertaken on born globals, specifically, the dynamics that propel the process concerned in speedily internationalizing SMEs in South Korea, are still at the emerging stage [64, 75]. Thus, the purpose of this research article is to analyses the present explanations of the phenomenon of 'born global', in particular within the context of South Korea with the objective of identifying the characteristics that can affect the rapid internationalization of their SMEs.

In order to attain this purpose, the paper provides detail analysis, discussion, and explanations to the topics on SMEs and their contribution to national economies, SMEs in South Korea, early internationalization of SMEs, explanations to born global concept and born globals in South Korea. The outcome of the analysis, elaborate discussions and observations on these topic areas provide conclusions to the paper. Finally, the paper highlights that wider empirical research is significant to this export-led country for understanding the specific characteristics that are responsible for the rapid internationalization of their SMEs with some directions for future research.

\section{SMEs and Their Contribution to National Economies}

SMEs are important and their significance is increasing in many industrialized countries. The small firm sector provides the muse for the whole economy in several countries because it plays a really vital role in job creation, innovation and therefore the long-run development in their economies [2, 5-12, 25, 39, 71].

Small firms' capabilities are recognized in terms of their flexibility, reaction time, and innovation capacity. Many writers point out that with the increasing trend of global economic production, much attention is drawn to the small firms' national and global competitiveness, market innovation, job creation in almost all economies and their capability of satisfying the niche markets $[25,39,65]$.

Despite small firms' importance within the world economy, what exactly constitutes a small firm still remains an issue, as there is no consistently agreed definition for a small firm. Therefore, small firm statistics are somewhat speculative arising uncertainty for readers and researchers. It has become more complicated as statistical definitions for these firms vary from country to country. For instance, in the USA, small firms generally are those that use fewer than five hundred individuals whereas, in Canada, firms that use fewer than a hundred are considered small firms [70]. Some countries also use turnover, capital employed, and the number of people employed or a combination of all three for definitions [71]. It appears that the definition of small firms is not universally the same. Therefore, the use of the internationally available literature on small firms in business-related research is an issue for concern of the researchers; as such literature does not follow a universally accepted definition of the small firm [32]. However, this article does not go into details of this unresolved issue which needs attention in the future. Nevertheless, business-related literature, which was classified as small firm literature by the individual international markets, was used in this article.

It is evident that small firms enter into international business within a shorter period than before and they are effectively carrying out their international businesses quickly. These globally active small companies have a propensity to grow much quicker than the small firms that serve solely domestic markets [2]. Thus, their global business activities are drawing great interest from researchers around the world.

\section{SMEs in South Korea}

As Eunsun [24] pointed out nearly 840, 000 small firms were formed during 2014 in South Korea where the population is approximately 50 million. This suggests that opening a business is a popular option for many South Koreans as it is a way to find employment. However, statistics show that the survival rate of these individual enterprises is remarkably low. For example, on average, only 60 percent of new SMEs are still in business after the first year and this percentage falls to less than 30 percent after five years [24]. The vital role of small firms' to the economic growth of many counties has been established recently [18]. Literature shows that most research attention has been concentrated on further promotion of the big Korean conglomerates [66]. Over the few years, however, Korean government emphasis has been more and more bound toward reassuring SMEs ' access to finance, markets, and technology, independent of a chaebol and large companies [59].

The establishment of the Small and Medium Business Administration in 1996, with regional offices at 11 locations to promote the development of local small businesses, is an example of the government initiative to strengthen the SME sector in South Korea. This was also a South Korean Government initiative to assist the small firms' sector of the country where the chaebol-dominated economic structure had impeded the development of the small firms' sector of the economy [58]. These family-owned companies of individual entrepreneurs are 
renowned brands in the world. For example, some prominent chaebol structures in South Korea are Samsung, Hyundai and LG Group which are managed by the founder and their family of the conglomerate. Even though these big companies shape the economic backbone of South Korea, SMEs are responsible for more than $80 \%$ of the jobs in the country [74]. This shows the significant contribution of SMEs' to the overall performance of the South Korean economy. Statistical information indicates that there is a surge of the export share of SMEs in South Korea from $31 \%$ to $43 \%$ for the period 1998 to 2001 [45].

Policy-makers so have stressed the importance of export development as a result of macro and microeconomic benefits advantages gained from international trade [12, 46]. International trade can lead to a rise in foreign currency reserves, increase job opportunities, produce backward and forward linkages, and eventually result in a rise of living standards. It can also produce companies with a competitive edge, develop their financial position, amplify manufacturing capabilities, and lift technological standards [22].

\section{Early Internationalization of SMEs}

In the current state of a more and more internationalized economy, several companies are intended to expand their business to worldwide markets. The theoretical approaches of the eclectic paradigm, the Uppsala staged theory and the network theory are developed with the aim of predominantly explaining the internationalization of the MNEs, which is a company doing their business activities in additional than one country. However, a firm's internationalization appears tough to make clear with these theories as a result of internationalization is not any longer restricted to large companies however progressively involves medium and small companies too. Therefore several researchers have argued that the growth of ICT, notably the Internet, permits speedy internationalization of companies that create them 'born global'. Thus the internationalization of these companies displays a new method that will not be explained by the existing theories of internationalization [10, 20, 29, 43].

Previous analysis found that exporters at first went through distinct stages in their internationalization method delineated as a progressive way of going global [33, 34]. Formerly, variations in language, culture and additionally the time-consuming speed of communication and transportation between international markets have created difficulties in getting the required market information that thus magnified the prospects of doing international business $[43,57,63]$.

The long-established approach of internationalization was a method within which a firm progressively inflated the number and mixture of the markets they undertake business. This staged model that illustrated the traditional way, believed that doing international business develop progressively over time and firms establish themselves domestically before turning into global markets. The model additional explains that firms selected to export to the markets in near proximity before considering distant and culturally completely different markets so as to reduce the uncertainty concerned in those markets where market information is inadequate. It seems that the psychic distance is that the major barrier and companies reduce this during the process of learning through experience $[33,34]$. The standard slow internationalization of companies explains the thought that management is not capable to take in applicable understanding, experience and market information speedily [40].

Although the staged theory that has centered on MNEs gained general acceptance in the world since its development within the Nineteen Seventies, numerous studies have questioned the soundness of this model as a result of the increasing variety of early internationalizing companies brought challenges to the standard models of internationalization. The most important argument has been that the standard models were unable to clarify the way of acting of companies that leapfrog or rising development of born globals that created a requirement for a new interpretation to internationalization $[1,21,27,43$, $54,57,61,63,68,69]$. Research on the link between company size and their propensity to export also is confusing since some research shows a positive relationship; some no noteworthy connection and others still argue that size plays a vital role [55]. The literature on born globals has revealed the potential of small firms' early internationalization. It is conjointly shown that these firms either have fully unheeded their home market while coming into the global markets or selected to enter the domestic market and global markets promptly $[49,55]$.

\section{Explanations to Born Global Concept}

International business literature has historically focused on large companies. Several MNEs are the developed type of giant, older domestic companies [19] that attracted the interest of researchers with their vital monetary influence. Large companies have long benefited major blessings over small firms since they need the resources to vie in global markets $[15,23,63]$. In spite of that, within the present business setting, it is doable for someone who holds international expertise and a reasonable amount of money to carry out business wherever within the world in a comparatively short time frame. The capability to spot global business prospects is thus not restricted to giant companies within the present business setting thanks to the benefits of affordable communication and transportation so new companies with inadequate resources are able to with success vie in international business [63]. 
Since the Nineteen Eighties, there has been an increasing interest in companies that do not pursue the traditional model of the growing primary in their domestic markets and so setting out to export. As an alternative, these firms commence their exportation promptly or at some stage in the establishment years of their initiation. This abrupt rise has led to a new type of exporters referred to as born globals [42, 49, 67], global start-ups [62], international new ventures [53], high technology start-ups [36]. Reports appeared within the press and educational journals within the late Nineteen Eighties and early Nineties regarding small firms internationalizing from their initiation or within the period of time $[31,50,63]$. There is literature evidence to show that such firms are reputable with internationally experienced business persons who could link resources from numerous countries to fulfill the demand of markets. The capability to ascertain and take advantage of global trading prospects is not solely restricted to giant corporations however firms with insufficient resources which might conjointly vie with success in global markets [52]. A study conducted in 1993 by the UN found a growing range of small firms found the traditional model of internationalization not applicable to them. This is considered a limitation of the traditional model of internationalization. Thus it suggested that the time frame necessary for the firms to internationalize has condensed from approximately ten years within the Eighties to four or five years within the Nineties OECD [60]. There is evidence to this effect that a great number of born globals found in Australia, the United States, Canada, Norway, France, and Denmark too [56, 67].

The empirical study of Moen [56] involved 335 and 70 small exporting firms that were operating in Norway and France respectively. According to this research that more than $50 \%$ of the firms that had been formed after 1990 could be described as born globals. It was discovered that the owners' or managers' intensity of international connectedness is one of the reasons for these companies to become born global. A detailed survey of the Australian Manufacturing Council and McKinsey and Co. undertook in Australia involved 300 high value-added manufacturing SMEs. Out of these companies, 60 participated in the focus group study. This study identified two types of exporting firms. One type had the characteristics of the traditional idea which described exporting firms who first established in their home market and then looked into possible growth through exports. However, their main focus of the business activity was intact with their home market. The average of these firms was 27 years with average exports of 20 percent of their sales. The other type of exporting firms with an average age of only 14 years had started their exporting activities within two years of formation. They have also been exporting 76 percent of their total sales. These firms were identified as born globals [7].

The explanations given for the prevalence of this rising development of born globals are delineating by varied trends that are happening within the present business atmosphere. Growing developments of niche markets, advancements in process and communication technologies, and the prominence receiving for international networks and associations have optimistically added to the potential of internationalization for all companies. The proficient use of transportation and market-friendly government policies is also proposed as the foremost explanation for the rising of born globals [42, 51].

A research study by Andersson and Wictor [3] based in Sweden that involved 89 hi-tech firms was able to identify only four born globals within their sample which indicates that born globals are still uncommon in Sweden. Based on this research Andersson and Wictor [3] argue that the companies with the owners who could see the worldwide business openings that others cannot see have the capability to make their companies born globals. It is suggested that these owners are also capable of using their own local and international networks for making their companies born globals.

The research study by Knight and Cavusgil [43] involved a survey of 900 randomly selected manufacturing small firms across the United States which was established in 1980 and after. The firms that exported more than $25 \%$ of their manufactured goods were selected for this study. Knight and Cavusgil [43] proposed early internationalization associated with innovative culture, knowledge, and capabilities. The knowledge of the firm predominantly facilitates as a vital resource of the internationalization. Therefore such companies are ready to augment their tactics from the utilization of knowledge-based resources in winning global markets early in their operations. The noteworthy features of these companies are that they instigate a global concept of their markets with the objective of accomplishing the company goals at the very early stage of creation.

As suggested by Knight and Cavusgil [43] the smaller size unique to new companies seems to gift a form of flexibility that has key edges for ensuing success in international markets. The point here is that the rigid feature of big and relatively old companies be inclined to wedge their innovativeness. Relatively less rigid small as well as new companies with their flexible character are likely to push the innovativeness of the company. This innovativeness of the company helps out the progress of company-specific knowledge and capabilities that add to company performance with market growth. The flexible nature of small and energetic companies takes this benefit to expand greater business performance by converting their originality into business activities [43, 47]. Knight and Cavusgil [43] put forward a clarification for born globals based on the knowledge established from RBV of the firm. Their rationalization proposes that the firm's resources are mainly central to build up strategies of the firm that suit varied business settings. Therefore it is the task of the globally-oriented managers of newly created small firms to 
build up distinctive and incomparable knowledge. This knowledge helps out the managers in intensifying greater global performance. Thus Knight and Cavusgil [43] argue that this exceptional knowledge generates essential company capabilities. Such capabilities bear the prospective to be a part of the firm culture which may even be tacit or distinctive to the firm $[13,14,30]$. It is proposed that technology, ICT, particularly, smooth the advancement of born globals' learning on their customers, competitors and economical channel dealings [43].

The literature indicates that the main focus of research analyzing born globals is within the sophisticated technology sectors as a result of these companies is distinct by fast technological alteration. The studies of Johnson [35] and Knight and Cavusgil [42] support this view. For example, Knight and Cavusgil [42] construed born global companies as generally undersized, technology-driven companies that enter into global markets from the initial days of their formation.

However, research studies undertaken in other sectors are also found although they are limited. For example, even trading companies provide examples of born globals. It is clear this emergent field is still in its infancy. Thus research focusing on other sectors will help to generalize the finding so far on born globals which are mainly based on high-tech firms $[3,49,68]$.

According to Rialp et al. [68], approximately one-third of research studies undertaken in the period 1993 to 2003 focused on the following main factors as being vital for small firms to compete internationally:

- the growing significance of niche markets that are being created worldwide

- technological developments which include manufacturing, transportation, and communication

- increasingly significance of universal networks

- capabilities of owner/managers who initiate the born global

Rialp et al. [68] state that these factors have not fully been integrated into theoretical frameworks used in past empirical research although a number of researchers have tried to establish their explanations by incorporating insights from the RBV view [13, 16]. For example, some authors suggest the RBV provides a holistic view of the firm since it explains the coordinated effect of resources and capabilities that provides the ability to market their product overseas [43]. In contrast, Rialp et al. [68] suggest that the combined application of multiple theories, mixed and improved conceptual approaches would make progress easier to presenting robust explanations of the early internationalization of small firms. Jones and Dimitratos [37] also suggest that consideration of both effects of internal and external environmental conditions of the firm would be able to provide exciting direction of research in this exercise.

This can be ascertained in a study of Fink and Kraus [26] that concerned a survey with 146 small and medium-sized firms in Austria, the Czech Republic, and Slovenia. The empirical study was carried out with the aim of exploring whether trust-based coordination is a rational justification for the internationalization practice of these firms. The end result of the analysis demonstrated that the growth of trust-based cooperation with global partners works optimistically for the internationalization of small firms [26].

The small companies in Austria were able to quickly internationalize by going in markets within the CEEC (Central and East European Countries). Cooperation theory explained the significance of the development and maintenance of trust-based cooperation with the global partners that cause the success of their global business. The owners' or managers' self-commitment was very important in developing this cooperative relationship and their psychic closeness to the CEEC countries a plus. Mutual trust and commitment were supported by common everlasting business dealings rather than short-run plans that encourage early defection. This helped companies in business to keep up sustainable trust-based cooperation relationships with minimum business disputes [26, 28].

Thus Fink and Kraus [26] argue that companies during this style of relationship may grow successively collectively and it makes company activities simple and helps them to avoid wasting resources. Fink and Kraus [26] also provide examples from Japan of trust-based relationships like 'Kairetsu'. They advise that companies should exploit the benefits of stable, long-run business relationships that carry a minimum level of disputes. The Japanese conception of 'Kyosei' may also make sure owners/managers of companies capture lessons in business diplomacy and responsibility for themselves and others while keeping to entrepreneurial attitudes and make earnings. Diplomacy helps out in business to construct trust and build up relationships that are thought-about the key to long-term accomplishments [38, 48].

Although company resources, the entrepreneurs, their networks and business factors are known as a number of the significant aspects in the early internationalization that lead small firms to born globals, modern technologies and lowering of trade barriers have additionally been identified as the way to amplify this tendency of internationalization $[3,37]$. However, Born-globals benefit way more interest than they are receiving, as their growth tactics may offer lessons for several different organizations around the globe.

\section{Born Globals in South Korea}

Although extensive research studies on the characteristics of born globals have been carried out in many countries, research studies on this topic undertaken in South Korea are extremely limited. It is a surprising observation as rapid internationalization is particularly vital to the economic growth strategy of South Korea 
which is an export-oriented country [75]. The South Korean economy has been trapped in the web of low growth and its capacity for job creation has also been rapidly weakening. Therefore the country was looking for ways to reboot the economy. Research evidence shows that born globals in South Korea are competitive and sustainable in the global market. As such, the South Korean government has recognized the born globals in the country as a source of economic revitalization [44]. In the light of the characteristics of Born Globals discussed in this paper and their importance to the global trade, Born Globals seems even much more important to South Korea as well. In South Korea, such a firm would have a relatively smaller domestic market size. Thus the survival of born globals primarily depends on the successful implementation of their internationalization. Considering the relatively small size of the South Korean market, it is feasible for the South Korean small and medium-sized companies to gain entry into foreign markets from the inception of forming the companies and attain excellent export performance for their long term sustainability. It can also be considered as a good strategy for such companies to break through and escape the trap in the web of low growth in South Korea. Thus a lot of policy attention has been focused on the role of born globals who can accomplish job creation and export expansion in tandem [44, 64].

Although, Yoon and Kim [75] defined born globals as "companies that find markets overseas less than six years after their foundations", "many previous studies defined an organisation that quickly globalizes as one that enters a foreign market within three years of its inception [44, p. 31]. In a research study undertaken in South Korea with the objective of identifying the distinctive aspects of the born globals in South Korea that involved 378 high-tech born globals found that the technological features of born globals have noteworthy consequences on their internationalization. It appears that there is a considerable correlation connecting the technological features of born globals and the CEO's world orientation and therefore the internationalization [75]. It was observed that most of the researchers utilized one or two technological features like technological capacity or technological innovation in their research studies [41, 73]. Based on these observations, Yoon and Kim [75] suggest that numerous technological features could influence the internationalization of SMEs in South Korea. However, Yoon and Kim [75] stressed the need for more detail research studies that involve diverse variables so as to achieve a more robust understanding of the contributing factors for SMEs to become born globals in South Korea.

Sung-soo [72] quoted from the head of the K-ICT Born2Global Center of South Korea, which is a major Korean authority beneath the Ministry of Science, ICT and Future Planning (MSIP), on the performance of the South Korean born globals stated that their performance was relatively poorer than those of their U.S., Chinese and
Singaporean counterparts. It appears that the South Korean firms' advanced technological capabilities were underestimated and failed to be publicized to a sufficient extent as the South Korean born globals were relatively weak in making connections with foreign companies mainly due to their weak linguistic and cultural capabilities. Therefore the K-ICT Born2Global Center is taking efforts to help South Korean born globals to improve their public relations (PR) and networking abilities by means of the center's public relations services.

Park [64] on his research has identified that very little research on Born Globals has been carried out in South Korea. There still remains much to be done, even if a few nascent studies of Born Globals in the country have already been done. Research is therefore required to achieve a better understanding of the roles of persons and also the dynamics of chance seeking in speedy internationalization. Although growing attention has been paid to born globals around the world, there has been very little analysis on rapidly internationalising SMEs within the context of Asian economies like South Korea. Moreover, there has been inadequate research, by means of large scale assessments, on the relations between key variables such as the international business expertise of managers and therefore the use of networks that provide the advantage of their SMEs to undertake global business activities. It is interesting to observe that SMEs steadily mature building solid associations with large companies in South Korea, because of the greater part of South Korean SMEs function in manufacturing and intermediate goods industries [64].

Lee [44] conducted empirical research with South Korean SMEs and gathered information from over a thousand SMEs. It is generally agreed that an SME in South Korea is a firm that has less than 300 employees. From the research with over a thousand SMEs, Lee [44] has used the responses received from 400 firms, which were considered as born globals, to analyze the various aspects of the firms. Lee [44] identified that there are many research outcomes to explain which firms are born globals; there are little empirical studies to understand their speed, scope, and scale. However, according to Lee [44], South Korean born globals are primarily different from their traditional SMEs. They are unique as they have frequently started with technology-based characteristics, equipped with strong entrepreneurial sense and they are venture-funded.

\section{Conclusions}

A review of the literature shows that established theories have built with the aim of principally illuminating the internationalization of large MNEs. This analysis offers substantiation that a company's internationalization is not restricted to MNEs but a considerable number of small companies are also entering into international business. 
Internationalization of these companies has been a speedy path that cannot easily be understood by the conventional theories of internationalization. Therefore many empirical studies have looked to clarifications as to what factors contributing to speedy internationalization and being born global.

Several of the factors that appear to contribute to this occurrence internationally are the rapid growth of ICT particularly the Internet, the growing trend of niche markets, development in process-related technologies, dynamic capabilities of owner/managers of companies and the growing importance of networks. Apart from these, the well-organized use of transportation and trade facilitation by governments has also been proposed as reasons for the existing trend of born global.

However, the review of the available literature indicates that factors that contribute to this phenomenon in South Korea are still at the emerging stage. This creates a research gap to investigate explanations for the phenomenon of born global within the market context of South Korea. As an export-led country, born globals play an important role in improving South Korea's competitiveness. This review has significant implications that propose that many characteristics can affect the internationalization of SMEs in South Korea even though they are still not precisely clear. It appears from the review that the research undertaken on internationalization of SMEs is relatively new and little empirical studies have been done in South Korea even though their rapid internationalization is extremely vital to this export-oriented country. Thus wider empirical research is significant to this country for understanding the specific characteristics that are responsible for the rapid internationalization of their SMEs. Results of such empirical studies can assist in undertaking even more comparative studies in export-oriented countries in the Southeast Asian region such as Japan and China in order to generalize the results.

\section{REFERENCES}

[1] O. Andersen. (1993), On the Internationalization process of firms: A critical analysis, Journal of International Business Studies, Vol. 24, No. 2, 209-230, 1993.

[2] S. Andersson, J. Gabrielsson, I. Wictor. International activities in small firms: examining factors influencing the internationalization and export growth of small firms, Canadian Journal of Administrative Sciences, Vol. 21, No. 1, 22-34, 2004.

[3] S. Andersson, I. Wictor. Innovative internationalization in new firms: born globals-the Swedish case, Journal of International Entrepreneurship, Vol. 1, No. 3, 249-275, 2003.

[4] A. Amarasena. Global Competitiveness of Exporting Firms:
Impact of the Internet on the Exporter-Importer Relationship, International Conference on Global Issues in Multidisciplinary Academic Research, February 01 - 02, TKP Conference Centre, Ichigaya, Tokyo, Japan, 2018.

[5] A. Amarasena. Current Trends in the International Business Environment, Universal Journal of Management, Vol. 5, No. 8, 381-394. 2017.

[6] A. Amarasena. Current Trends in the International Business Environment, Seoul International Conference on Social Sciences and Management, 07-09 February, Seoul, South Korea, 2017.

[7] A. Amarasena. Forces that Propel SMEs to become Born Globals in South Korea, Annual Conference on Management and Social Science, August 14-16, Osaka, Japan, 2017.

[8] A. Amarasena. Small firms exporting to Asia: an innovative export model, The Journal of Internet Business, Issue 11, 1-38, 2013.

[9] A. Amarasena. The role of the Internet in Australian small firms exporting to Sri Lanka: An innovative export model, $2^{\text {nd }}$ International Conference on Business and Information (ICBI), Faculty of Commerce and Management Studies, University of Kelaniya, Colombo, Sri Lanka, $20^{\text {th }}$ October, 2011.

[10] A. Amarasena and S. Colombage. Exporting in the Asian century: the dynamics of success, Sid Harta Publishers, Melbourne, 2017.

[11] A. Amarasena. The Internet in the Performance of Small Exporting Firms: A Developed to Developing Country Market Context, Journal of Internet Business, Issue 5, 51-80, 2008.

[12] A. Amarasena, S. Colombage. An emerging Asian niche market for exports, Thunderbird International Business Review, Vol. 53, No. 4, 525-539, 2010.

[13] E. Autio, H. Sapienza, J. Almeida. Effects of age at entry, knowledge intensity and imitability on international growth, Academy of Management Journal, Vol. 43, No. 5, 909-1014, 2000.

[14] J. Barney. Firm resources and sustained competitive advantage, Journal of Management, Vol. 17, No. 1, 99-120, 1991.

[15] P. J. Buckley, M. Casson. The Future of the Multinational Enterprise, Macmillan, London. 1976.

[16] O. Burgel, G. C. Murray. The international market entry choices of start-up companies in high-technology industries, Journal of International Marketing, Vol. 8, No. 2, 33-62, 2000.

[17] G. Cannone, E. Ughetto. Born-globals: A cross-country survey on high-tech start-ups, International Business Review, Vol. 23, 272-283, 2014.

[18] M. A. Carree, A. R. Thurik. The Impact of Entrepreneurship on Economic Growth in Hand Book of Entrepreneurship, eds. D. B. Audretsch and Z. J. Acs, Kluwer Academic Publishers, Boston, 2002.

[19] A. D. Jr. Chandler. The evolution of modern global competition in Competition in global industries, ed. M. E. 
Porter. Harvard Business School Press, Boston, 1986.

[20] P. Chetty. A strategic approach to internationalization: a traditional versus a 'born-global' approach", Journal of International Marketing, Vol. 12, 57-81, 2004.

[21] N. E. Coviello, H. J. Munro, H. J. Growing the entrepreneurial firm: Networking for international market development, European Journal of Marketing, Vol. 29, 7, 49-61, 1995.

[22] M. R. Czinkota, P. Rivoli, I. A. Ronkainen. International Business, $2^{\text {nd }}$ edn, The Dryden Press, Orlando, FL.1992.

[23] J. H. Dunning. International Production and the Multinational Enterprise, Allen and Unwin, London, 1981.

[24] C. Eunsun. What 'Entrepreneurship' Means to South Koreans, The Diplomat. http://thediplomat.com/2016/01/w hat-entrepreneurship-means-to-south-koreans/, 2016.

[25] D. Fink. (1998), “Guidelines for the Successful Adoption of Information Technology in Small and Medium-sized Enterprises", International Journal of Information Management, Vol. 18, No. 4, 243-253, 1998.

[26] M. Fink, S. Kraus. Mutual trust as a key to internationalization of SMEs, Management Research News, Vol. 30, No. 9, 674-688, 2007.

[27] R. A. Fletcher. A holistic approach to internationalization, International Business Review, Vol. 10, 25-49, 2001.

[28] G. Gemser, M. J. Brand, A. Sorge. Exploring the internationalization process of small business: a study of Dutch old and new economy firms, Management International Review, Vol. 44, No. 2, 127-177, 2004.

[29] J. Gluckler. A relational assessment of international market entry in management consulting, Journal of Economic Geography, Vol. 6, No. 3, 369-393, 2006.

[30] R. M. Grant. Toward a knowledge-based theory of the firm, Strategic Management Journal, Vol. 17, Winter Special Issue, 109-122, 1996.

[31] U. Gupta. Small firms aren't waiting to grow up to go global, The Wall Street Journal, December 5: B2, 1989.

[32] S. Holmes, B. Gibson, B. Definition of small business, The University of Newcastle $<$ http://www.smallbusiness.org.a $\mathrm{u} /$ sbc/publications/sbc004.pdf $>, 2001$.

[33] J. Johanson, J. E. Vahlne. The internationalization process of the firm: a model of knowledge development and increasing foreign market commitment, Journal of International Business Studies, Vol. 8, No. 1, 23-32, 1977.

[34] J. Johanson, J. E. Vahlne. The mechanism of internationalization, International Marketing Review, Vol. 7, 11-24, 1990.

[35] J. Johnson. Factors influencing the early internationalization of high technology startups: US and UK evidence, Journal of International Entrepreneurship, Vol. 2, No. 1-2, 139-154, 2004.

[36] V. K. Jolly, M. Alahuhta, J. P. Jeannet. Challenging the incumbents: How high technology start-ups compete globally, Journal of Strategic Change, Vol. 1, 71-82, 1992.

[37] M. V. Jones, P. Dimitratos. Editorial-Entrepreneurial strategy: being in the right place, at the right time? Journal of International Entrepreneurship, Vol. 1, 243-247, 2003.

[38] R. Kaku. "Kyosei”, in Corporate Diplomacy: principled leadership for the global community, eds. R. Trice., M. Hasegawa and M. Kearns, The Centre for Strategic and International Studies, Washington, DC., 1995.

[39] T. E. Kaplan, I. W. Johnson, G. C. Pearce, G. George. The strategic role of communication technology in small business: Where we are and where we should be going, American Business Review, Vol. 15, No. 1, 86-91, 1997.

[40] G. Knight. Born Global Firms: Evolution of a Contemporary Phenomenon in Entrepreneurship in International Marketing. Published online: 02 Feb 2015; 3-19, 2015.

[41] N. Kumar, N. S. Siddharthan. Technology, Market Structure and Internationalization: Issues and Policies for Developing Countries; Routledge: Abingdon-on-Thames, UK, 2013.

[42] G. A. Knight, S. T. Cavusgil. The born global firm: A challenge to traditional internationalization theory, Advances in International Marketing, Vol. 8, 11-26, 1996.

[43] G. A. Knight, S. T. Cavusgil. Innovation, organisational capabilities, and the born-global firm, Journal of International Business Studies, Vol. 35, No. 2, 124-141, 2004.

[44] Y. Lee. Indentifying the Characteristics and Performance of Born Global Start-up in Korea, Industrial Economic Review, No. 5, Vol. 22, 28-41, 2017.

[45] Lee, J. H. SME Policies of Korea - June 2010, Small and Medium Business Administration (SMBA), http://www.oe cdkorea.org/Download/Governance/Manager/General/File/ 201007/, 2010.

[46] L. C. Leonidou, C. S. Katsikeas. The export development process: an integrative review of empirical models", Journal of International Business Studies, Vol. 27, No. 3, 517-552, 1996.

[47] A. Y. Lewin, S. Massini. Knowledge creation and organisational capabilities of innovating and imitating firms, in Organisations as Knowledge Systems, eds. H. Tsoukas and N. Mylonopoulos, Palgrave, Basingstoke, 2003.

[48] M. London. Principled leadership and business diplomacy: A practical, values-based direction for management development, Journal of Management Development, Vol. 18, No. 2, 170-192, 1999.

[49] T. K. Madsen, P. Servais, P. The internationalization of born globals: an evolutionary process? International Business Review, Vol. 6, No. 6, 561-583, 1997.

[50] R. A. Mamis. Global start-up, Inc., August, Vol. 11, No. 8, 38-47, 1989.

[51] P. P. McDougall, B. M. Oviatt. International entrepreneurship: The intersection of two research paths, Academy of Management Journal, Vol. 43, No. 5, 902-906, 2000.

[52] P. P. McDougall, B. M. Oviatt. Global start-ups: new venture without geographic limits, The Entrepreneurship Forum, winter, 1-5, 1991.

[53] P. McDougall, S. Shane, B. M. Oviatt. Explaining the 
formation of international new ventures: The limits of theories from international business research, Journal of Business Venturing, Vol. 9, 469-487, 1994.

[54] R. B. McNaughton. Determinants of Time-Span to Foreign Market Entry: Evidence from Canadian Micro-Businesses, Journal of Euro Marketing, Vol. 9, No. 2, 99-112, 2000.

[55] R. B. McNaughton, The number of export markets that a firm serves: process models verses the born-global phenomenon, Journal of International Entrepreneurship, Vol. 1, 297-311, 2003.

[56] O. Moen. The born globals: A new generation of small European exporters, International Marketing Review, Vol. 19, No. 2/3, 156-175, 2002.

[57] O. Moen, P. Servais. Born global or gradual global? Examining the export behaviour of small and medium-sized enterprises, Journal of International Marketing, Vol. 10, No. 3, 49-72, 2002.

[58] H. Mukoyama. Promotion of Small Business Development in South Korea, Sakura Institute of Research, Inc., Japan Research Institute, RIM, No. 44 https://www.jri.co.jp/engli sh/periodical/rim/1999/], 1999.

[59] J. B. Nugent, S. Yhee. Small and Medium Enterprises in Korea: Achievements, Constraints and Policy Issues, The International Bank for Reconstruction and Development / The World Bank 1818 H Street, N.W. Washington, D.C. 2001.

[60] OECD, Globalisation and Small and Medium Enterprises, OECD, Paris, 1997.

[61] M. J. Oesterle. Time span until internationalization: foreign market entry as a built-in mechanism of innovation, Management International Review, Vol. 37, No.2, 125-149, 1997.

[62] B. M. Oviatt, P. P. McDougall. Toward a theory of international new ventures, Journal of International Business Studies, Vol. 25, No. 1, 45-64, 1994.

[63] B. M. Oviatt, P. McDougall. Toward a theory of international new ventures, Journal of International Business Studies, Vol. 36, 29-41, 2005.

[64] T. Park. Investigating "born globals" in South Korea: their antecedents and performance, $\mathrm{PhD}$ Thesis, the Business School, The University of Hull, 2010.

[65] V. Pospisil, Global paradox: Small is powerful, Industry Week, Vol. 234, No. 14, 29-33, 1994.

[66] P. Regnier. Small business and industrialisation in South Korea, Asia Pacific Journal of Management, Vol. 9, Issue1, 107-117, 1992.

[67] M. W. Rennie. Global competitiveness: born global, McKinsey Quarterly, No. 4, 45-52, 1993.

[68] A. Rialp, J. Rialp, G. A. Knight. The phenomenon of early internationalizing firms: what do we know after a decade (1993-2003) of scientific inquiry? International Business Review, No. 14, No. 2, 147-166, 2005.

[69] L. Rutashobya, J. Jaensson. Small firms' internationalization for development in Tanzania: exploring the network phenomenon, International Journal of Social Economics,
Vol. 31, No. 1/2, 159-172, 2004.

[70] Small Business Research and Policy, Industry Canada's small business policy branch strategic plan 2003-04 to 2005-06, Canada, 2003.

[71] J. D. Storey. Understanding the Small Business Sector, Routledge, London, 1994.

[72] H. Sung-soo. K-ICT Born2Global Center to Enhance Promotion of Korean Start-ups Abroad, Business Korea, 30 May 2016.

[73] S. Tanev. Global from the start: The characteristics of born-global firms in the technology sector, Technology Innovation Management Review, 5-8, 2012.

[74] L. Williamson. South Korea's small businesses fight for survival, BBC News, Seoul 17 Aug 2011 [http://www.bbc. com/news/business-14554015], 2001.

[75] J. Yoon, D. Kim. Empirical Relationships among Technological Characteristics, Global Orientation, and Internationalization of South Korean New Ventures, Sustainability, Vol. 8, 1254, 1-13, 2016. 